\title{
INTERAKSI DAN KOMUNIKASI DOSEN DAN MAHASISWA DALAM PROSES PENDIDIKAN
}

\author{
ABDUL MALIK ISKANDAR ${ }^{1}$, RASYIDAH ZAINUDDIN ${ }^{2}$ \\ 1FKIP Universitas Megarezki Makassar, ${ }^{2}$ Universitas Bosowa \\ Abdul.malikiskandar@yahoo.com, georgiana.aan07@gmail.com
}

\begin{abstract}
Abstrak
Keberhasilan seorang mahasiswa dalam dunia akademik dipengaruhi oleh banyak faktor. Salah satu faktor tersebut adalah peranan dosen penasehat akademik dalam memberikan arahan atau bimbingan atas problem yang dialami mahasiswa selama mengikuti proses perkuliahan. Oleh karena itulah artikel ini dimaksudkan untuk mengungkapkan proses pembimbingan yang berlangsung antara dosen dengan mahasiswa. Secara khusus proses pembimbingan tersebut terkait erat dengan persoalan komunikasi antar individu yang sifatnya interpersonal. Dalam konteks tersebut, maka diadakan penelitian ini berlangsung di Program Studi Pendidikan Sosiologi FKIP Universitas Mega Rezki Makassar. Penelitian ini bersifat deskriptif kuantitatif dengan pendekatan survei. Populasi penelitian ini adalah semua mahasiswa prodi sosiologi sebanyak 450 orang. Sampel yang ambil adalah 250 orang sebagai responden dengan menggunakan teknik stratified random sampling dari tiga angkatan yang masih aktif yaitu angkatan 2016, 2017, dan 2018. Pengumpulan data menggunakan kuesioner, wawancara, dan studi literatur. Analisis data menggunakan tabulasi frekuensi. Hasil penelitian menunjukkan (1) intensitas interaksi dan komunikasi interpersonal terkategori tinggi dengan capaian nilai 87. (2) dimensi dalam interaksi dan komunikasi interpersonal memiliki capaian nilai bervariasi, yaitu: keterbukaan (59,2\% kategori rendah); dukungan (54\% kategori rendah); Empati (46\% kategori tinggi); rasa positif (43,2\% kategori rendah); kesetaraan (66,8\% kategori tinggi). Tiga dari dimensi tersebut terkategori rendah dan dua terkategori tinggi. Kesimpulan penelitian ini adalah interaksi dan komunikasi interpersonal penasehat akademik dengan mahasiswa berlangsung dengan frekuensi dan intensitas tinggi, tetapi tidak maksimal selama komunikasi berlangsung. Mahasiswa sering melakukan konsultasi namun tidak berkualitas.
\end{abstract}

Kata Kunci: Interaksi, Komunikasi, Interpersonal, Empati, Keterbukaan.

\section{PENDAHULUAN}

Dalam proses kehidupan sosial umat manusia, hubungan antar individu yang satu dengan individu lainnya merupakan keniscayaan. Secara spesifik, hubungan individu tersebut terwujud dalam bentuk komunikasi dan interaksi sebagai representasi penguatan. Komunikasi ini juga yang merupakan penciri atau karakteristik keberadaan manusia secara sosial. ini berarti bahwa interaksi dan komunikasi merupakan sesuatu yang inheren dan terintegrasi dalam diri manusia sosial. Bila ini tidak terwujud maka akan terisolasi dari lingkungan sekitarnya dan 
bahkan dari kehidupan sosialnya. Hal ini menunjukkan bahwa pengaruh keterisolasian tersebut dapat menimbulkan depresi mental, dan pada akhirnya orang akan kehilangan keseimbangan. ${ }^{1}$

Secara mendasar, komunikasi merupakan suatu proses sosial yang sangat mendasar dan vital dalam kehidupan manusia. Hal tersebut disebabkan oleh karena setiap manusia dari dulu sampai seterusnya, memiliki bagian dalam dirinya keinginan atau hasrat menjalani kehidupan dan aturan-aturannya melalui komunikasi. Penyebab lainnya adalah setiap individu memiliki kemampuan untuk berkomunikasi dengan individu-individu lainnya yang dengan kredibilitasnya sebagai seorang anggota masyarakat tetap ada. Kondisi demikian memberi kesempatan individu tersebut untuk tetap hidup, sedangkan tidak adanya kemampuan tersebut pada individu secara umum dianggap sebagai suatu bentuk patologi kepribadian yang serius.

Dalam konteks tersebut di atas, Anita et.all menyatakan bahwa komunikasi yang efektif ditandai dengan hubungan interpersonal yang baik. Kegagalan komunikasi sekunder terjadi, bila isi pesan dapat dipahami, tetapi hubungan diantara komunikan menjadi rusak. "Komunikasi interpersonal yang efektif meliputi banyak unsur, tetapi hubungan interpersonal barangkali yang paling penting."2

Definisi lain juga diutarakan oleh Littlejhon dalam Theories of Human Communication bahwa komunikasi antarpribadi (interpersonal communication) merupakan komunikasi antara individu-individu. Pengertian lainnya Komunikasi antarpribadi adalah komunikasi yang berlangsung dalam situasi tatap muka antara dua orang atau lebih, baik secara terorganisasi maupun pada kerumunan orang. Komunikasi Interpersonal adalah adanya komunikasi secara langsung atau face-toface communication maupun melalui media. Bila ada cara berkomunikasi dengan

\footnotetext{
${ }^{1}$ Hafied Cangara, Komunikasi Politik Konsep, Teori dan Strategi, (Jakarta: PT. Raja Grafindo Persada, 2007), h. 34.

${ }^{2}$ Jalaluddin Rahmat, Psikologi Komunikasi, (Bandung: Remaja Rosdakarya, 2004), h. 119.
} 
menggunakan media maka terdapat kelompok maya, misalnya melalui internet (chatting, face book, email, dan lain-lain). ${ }^{3}$

Dalam proses perkembangannya kemudian, komunikasi kelompok tersebut mengalami perkembangan secara pesat dari waktu ke waktu. Tidak asing bagi publik yang sering membaca atau mendengar istilah komunikasi interpersonal atau komunikasi antarpribadi. Istilah ini nampak sederhana namun pemahaman masyarakat luas mengenai komunikasi, justeru mengesankan pengertian komunikasi interpersonal.

Komunikasi interpersonal merupakan suatu proses penyampaian pesan dari seseorang kepada orang lain atau pihak lain. Menurut pemahaman seperti ini, komunikasi dikaitkan dengan pertukaran informasi yang bermakna dan harus membawa hasil di antara orang-orang yang berkomunikasi. Komunikasi interpersonal menghendaki informasi atau pesan dapat tersampaikan dan hubungan di antara orang yang berkomunikasi dapat terjalin. Oleh karena itu setiap orang apapun tujuan mereka, dituntut memiliki keterampilan komunikasi interpersonal agar mereka bisa berbagi informasi, bergaul dan menjalin kerjasama untuk bisa bertahan hidup.

Selain itu, ada sejumlah kebutuhan di dalam diri manusia yang hanya dapat dipuaskan lewat komunikasi dengan sesamanya. Oleh karena itu, penting bagi kita menjadi terampil berkomunikasi. Komunikasi berhubungan dengan perilaku manusia dan kepuasan terpenuhinya kebutuhan berinteraksi dengan manusiamanusia lainnya. Setiap orang membutuhkan hubungan sosial dengan orang-orang lainnya dan kebutuhan ini terpenuhi melalui pertukaran pesan yang berfungsi sebagai jembatan untuk mempersatukan manusia yang satu dengan manusia lainnya, yang tanpa berkomunikasi akan terisolasi.

Selanjutnya, ada beberapa peranan yang disumbangkan oleh komunikasi antarpribadi dalam rangka menciptakan kebahagiaan hidup manusia. Pertama, komunikasi antar pribadi membantu perkembangan intelektual dan sosial individu. Perkembangan manusia sejak masa bayi sampai masa dewasa mengikuti

\footnotetext{
${ }^{3}$ Wiryanto, Pengantar Ilmu Komunikasi (Jakarta: PT. Grasindo, 2004), h. 78.
} 
pola semakin meluasnya ketergantungan individu pada orang lain. Diawali dengan ketergantungan atau komunikasi yang intensif dengan ibu pada masa bayi, lingkaran ketergantungan atau komunikasi itu menjadi semakin luas dengan bertambahnya usia. Bersamaan proses itu, perkembangan intelektual dan sosial sangat ditentukan oleh kualitas komunikasi dengan orang lain itu. Kedua, identitas atau jati diri terbentuk dalam dan lewat komunikasi dengan orang lain. Selama berkomunikasi dengan orang lain, secara sadar maupun tidak sadar mengamati, memperhatikan dan mencatat dalam hati semua tanggapan yang diberikan oleh orang lain terhadap diri orang lain. Seseorang menjadi tahu bagaimana pandangan orang lain itu tentang dirinya. Berkat pertolongan komunikasi dengan orang lain seseorang dapat menemukan dirinya, yaitu mengetahui siapa dirinya sebenarnya. Ketiga, dalam rangka memahami realitas di sekeliling serta menguji kebenaran kesan-kesan dan pengertian yang dimiliki tentang dunia sekitarnya, perlu membandingkannya dengan kesan-kesan dan pengertian orang lain tentang realitas yang sama. Tentu saja, pembandingan sosial (social comparison) semacam itu hanya dapat dilakukan lewat komunikasi dengan orang lain. Keempat, kesehatan mental sebagian besar juga ditentukan oleh kualitas komunikasi atau hubungan dengan orang lain, lebih-lebih orang-orang yang merupakan tokohtokoh signifikan (significant figures). Bila hubungan dengan orang lain diliputi berbagai masalah, maka sering berdampak pada perasaan seperti merasa sedih, cemas, frustrasi. Bila kemudian seseorang menarik diri dan menghindar dari orang lain, maka rasa sepi dan terasing yang mungkin dialami pun tentu akan menimbulkan penderitaan, bukan hanya penderitaan emosional atau batin, bahkan mungkin juga penderitaan fisik. ${ }^{4}$

Agar merasa bahagia, dibutuhkan konfirmasi dari orang lain, yakni pengakuan berupa tanggapan dari orang lain yang menunjukkan bahwa diri kita normal, sehat dan berharga. Lawan dari konfirmasi adalah diskonfirmasi, yakni penolakan dari orang lain berupa tanggapan yang menunjukkan bahwa diri

\footnotetext{
${ }^{4}$ Johnson, D.W. Reaching Out. Interpersonal Effectiveness and Self-Actualization. (Englewood Cliffs: Prentice-Hall, 1981), h. 55.
} 
seseorang abnormal, tidak sehat dan tidak berharga. Semuanya itu hanya diperoleh lewat komunikasi antarpribadi, komunikasi dengan orang lain.

\section{KAJIAN PUSTAKA}

\section{Interaksi Sosial}

Interaksi sosial yang sering disebutkan adalah hubungan timbal balik antara individu dengan individu lain atau kelompok. Interaksi sosial merupakan proses saling memengaruhi tindakan individu atau kelompok melalui simbolsimbol dan bahasa. ${ }^{5}$

Ada dua syarat terjadinya interaksi sosial, yaitu kontak dan komunikasi. Kontak sosial merupakan tahap awal memungkinkannya terjadi interaksi. Komunikasi adalah proses terjadinya aksi-reaksi, hubungan timbal balik yang terwujud dalam interaksi itu sendiri. ${ }^{6}$

Ciri-ciri interaksi sosial adalah: (1) ada hubungan timbal balik, (2) ada reaksi, (3) dilakukan oleh 2 orang atau lebih, (4) muncul pola aksi-reaksi yang menyesuaikan norma. Adapun tujuan orang melakukan interaksi adalah: (1) ingin didengar, (2) menjalin keakraban, (3) resolusi konflik, (4) diplomasi, (5) belajar. ${ }^{7}$

\section{Pengertian Komunikasi}

Secara etimologi kata "komunikasi" berasal dari kata latin "communis" yang merupakan dasar kata bahasa Inggris “common” yang berarti sama. Dari kata ini berkembang menjadi 'communicatus" (bahasa latin) dalam bahasa Inggris "communication", yang berarti pekabaran atau perhubungan. Dalam bahasa indonesia kata ini bermakna "komunikasi" yang berarti berbagi atau menjadi milik bersama.

Komunikasi dipahami melalui berbagai macam rumusan antara lain:

\footnotetext{
${ }^{5}$ Soerjono Soekanto, Pengantar Sosiologi (Jakarta: Rajagrafindo Persada, 1990), h. 16.

${ }^{6}$ Soerjono Soekanto, Pengantar Sosiologi, h.17.

${ }^{7}$ Soerjono Soekanto, Pengantar Sosiologi, h.18.
} 
1. Komunikasi adalah proses pembentukan penyampaian, penerimaan dan pengelolaan pesan yang terjadi dalam diri seseorang dan atau dua orang atau lebih dengan tujuan tertentu. ${ }^{8}$

2. Komunikasi adalah pengiriman dan penerimaan pesan atau berita antara dua orang atau lebih dengan cara yang tepat sehingga pesan yang dimaksud dapat dipahami. ${ }^{9}$

3. Bernard Berelson dan Steiner: Communication is the transmission of information. $^{10}$

4. Everett M. Rogers menyatakan, komunikasi adalah proses mengalihkan suatu ide dari sumber kepada satu penerima atau lebih dengan maksud untuk mengubah tingkah laku mereka. ${ }^{11}$

Setelah menyimak beberapa definisi di atas maka secara esensial komunikasi diartikan sebagai penyampaian informasi dari seseorang kepada orang lain. Kesuksesan komunikasi terletak pada saling pengertian antara pihak pengirim dan penerima informasi.

Komunikasi adalah sebagai penyajian atau pertukaran informasi antara orang atau proses dengan mana sebuah pesan disampaikan dari seorang atau lebih pengirim kepada seorang atau lebih penerima. ${ }^{12}$

Dari pengertian yang dikemukakan di atas, ditemukan unsur-unsur komunikasi yang meliputi adanya tujuan tertentu, adanya sumber, pesan, media, penerima, efek dan umpan balik. Dengan demikian komunikasi merupakan satu bagian penting dan aspek yang amat kompleks dalam kehidupan manusia. Bahkan komunikasi merupakan kebutuhan hidup yang paling mendasar dengan mana

\footnotetext{
${ }^{8}$ Sendjaja, Sasa Djuarsa, dkk., Teori Komunikasi (Jakarta: Universitas Terbuka, 1993), h. 8.

${ }^{9}$ Deddy Mulyana, Ilmu Komunikasi Suatu Pengantar (Bandung: PT. Rosda Karya, 2008), h. 67 .

${ }^{10}$ Stephen W. Littlejohn, Theories of Human Communication, Fifth Edition, (Humboldt State University, Wadsworth Publishing Company, 1995), h. 5.

${ }^{11}$ Hafied Cangara, Pengantar Ilmu Komunikasi (Jakarta: PT. Raja Grafindo Persada, 1998), h, 13.
} 1990), h. 43.

${ }^{12}$ A.S. Achmad, Manusia dan Informasi (Ujung Pandang: Hasanuddin University Press, 
manusia saling melakukan interaksi sosial antara sesamanya dengan perantaraan komunikasi. Melalui interaksi sosial, manusia mendapatkan informasi tentang segala yang dibutuhkan untuk memenuhi kelangsungan hidup.

\section{Komunikasi Interpersonal}

Komunikasi antarpribadi adalah proses komunikasi yang berlangsung antara dua orang atau lebih secara tatap muka, seperti yang dinyatakan R. Wayne Pace bahwa "interpersonal communication is communication involving two or more people in a face to face setting " ${ }^{13}$

Menurut sifatnya, komunikasi antar peribadi dapat dibedakan atas dua macam, yakni komunikasi Diadik dan komunikasi kelompok kecil. Komunikasi didik ialah proses komunikasi yang berlangsung antara dua orang dalam situasi tatap muka. Sedangkan komunikasi kelompok kecil ialah proses komunikasi yang berlangsung antara tiga orang atau lebih secara tatap muka.

Komunikasi antarpribadi adalah komunikasi yang dilakukan antara seseorang dengan orang lain dalam suatu masyarakat maupun organisasi (bisnis dan nonbisnis), dengan menggunakan media komunikasi tertentu dan bahasa yang mudah dipahami (informal) untuk mencapai suatu tujuan tertentu. ${ }^{14}$ Komunikasi antarpribadi didefinisikan oleh Joseph A. Devito dalam bukunya "The Interpersonal Communication Book". ${ }^{15}$ Proses pengiriman dan penerimaan pesanpesan antara dua orang atau antara sekelompok kecil orang-orang, dengan beberapa efek dan beberapa umpan balik seketika".

Berdasarkan pengertian tersebut, paling tidak ada empat hal penting yang perlu diperhatikan, antara lain: (a) Bertatap muka (face to face). (b) Komunikasi dilakukan oleh dua orang atau lebih. (c) Menggunakan media tertentu, misalnya telepon, telepon selular, atau bahasa yang digunakan bersifat informal (tidak baku), dapat menggunakan bahasa daerah, bahasa pergaulan, atau bahasa

\footnotetext{
${ }^{13}$ Hafied Cangara, Komunikasi Politik Konsep, Teori dan Strategi, h. 54.

${ }^{14}$ Djoko Purwanto, Komunikasi Bisnis, (Jakarta: Penerbit Erlangga, 2006), h. 20.

${ }^{15}$ Onong Uchjana Effendy, Ilmu Komunikasi Teori dan Praktek, (Bandung: PT. Remaja Rosdakarya, 2003), h. 78.
} 
campuran. (d) Tujuan yang ingin dicapai dapat bersifat personal (pribadi) bila komunikasi terjadi dalam suatu masyarakat; dan untuk pelaksanaan tugas pekerjaan bila komunikasi terjadi dalam suatu organisasi.

\section{METODE PENELITIAN}

Penelitian ini adalah deskriptif kuantitatif dengan pendekatan survei. Populasi penelitian ini adalah seluruh mahasiswa pendidikan sosiologi FKIP Universitas Mega Rezki Makassar sebanyak 450 orang. Sampel yang ditentukan sebanyak 250 orang menggunakan Teknik Stratified Random Sampling dari 3 angkatan yaitu 2016, 2017, dan 2018. Teknik pengumpulan data menggunakan kuesioner, wawancara, dan studi literatur. Teknik analisis data menggunakan tabulasi frekuensi dan skala Likert.

\section{HASIL PENELITIAN DAN PEMBAHASAN}

\section{Intensitas Interaksi dan Komunikasi}

Interaksi dan komunikasi interpersonal yang berlangsung antara dosen sebagai penasihat akademik dengan mahasiswa sangat penting dilakukan untuk mengarahkan, membimbing, membantu memecahkan masalah yang dihadapinya. Keterlibatan Penasehat Akademik selaku seorang komunikator terhadap mahasiswa diharapkan dapat menjadi media untuk meyampaikan pesan bagi komunikan.

Uraian tentang intensitas interaksi dan komunikasi antara penasihat akademik terhadap mahasiswa terkait pengkonsultasian hasil belajar tergambar dalam gambar 1 berikut ini : 
Gambar 1. Sebaran Mahasiswa Berkonsultasi kepada Penasehat Akademik (PA) tentang Hasil Belajar

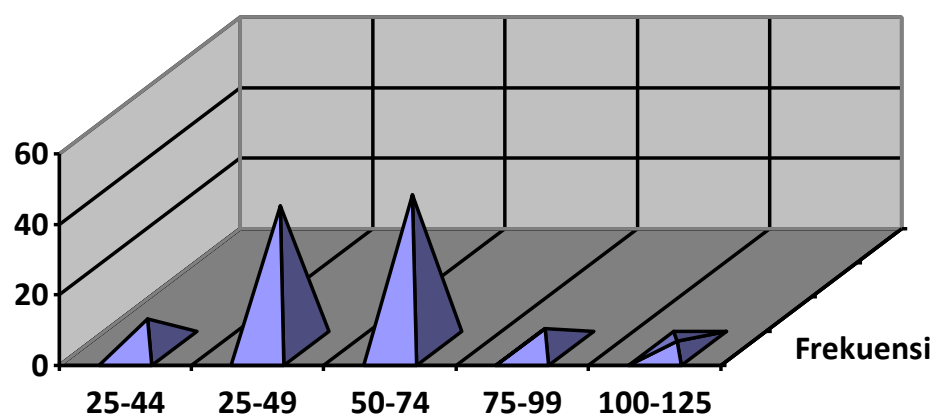

$\square$ Frekuensi $\square \square \square$

Sumber: Olahan Kuesioner (2018)

Gambar 1 di atas menunjukkan adanya pengakuan mahasiswa tentang intesitas mahasiswa dalam mengkonsultasikan hasil belajar ke penasehat akademik (PA) bervariasi. Dari 250 responden, terdapat 5 orang atau $2.0 \%$ yang mengatakan sangat tinggi, 14 orang atau 5.6\% yang mengatakan tinggi, 109 orang atau $43.6 \%$ yang mengatakan cukup, 101 orang atau $40.4 \%$ yang mengatakan rendah, dan 21 orang atau $8.4 \%$ lainnya yang mengatakan sangat rendah.

Gambar 2. Sebaran Frekuensi Durasi Mahasiswa Berkonsultasi kepada Penasehat Akademik (PA) tentang Hasil Belajar

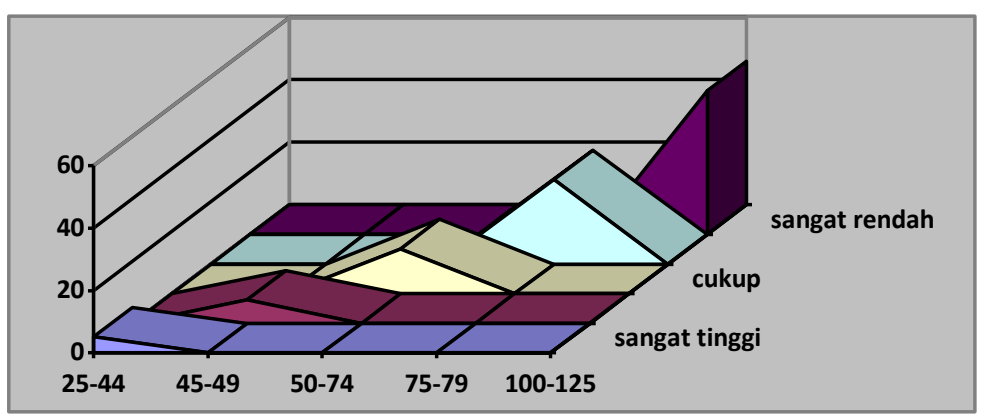

Sumber: Olahan Kuesioner (2018)

Berdasarkan gambar 2 di atas dapat dijelaskan bahwa durasi pengakuan mahasiswa dalam mengkonsultasikan hasil belajar ke Penasehat Akademik bervariasi. Dari 250 responden, terdapat 150 orang atau $60 \%$ yang mengatakan konsultasi ke penasehat akademik antara 0-4 menit, 62 orang atau $24.8 \%$ yang 
menyatakan antara 5-9 menit, 39 orang atau $15.6 \%$ yang menyatakaan antara 1014 menit, 35 orang atau 14\% yang menyatakan 15-19 menit, dan 24 orang lainnya atau $9.6 \%$ yang menyatakan lebih dari 20 menit.

Selanjutnya, berdasarkan indikator di atas yaitu tingkat intensitas dan durasi berlangsungnya Komunikasi Interpersonal Penasehat Akademik (PA) dengan Mahasiswa maka diperoleh nilai rata-rata (mean) sebesar 84.20, nilai tengah (median) sebesar 84, nilai yang sering muncul (modus) adalah 87, dan standar deviasinya adalah 5.94. Dengan demikian tingkat intensitas komunikasi interpersonal penasehat akademik masuk dalam ketegori tinggi. Kategori ini tinggi didasarkan pada interval standar penilaian intensitas komunikasi interpersonal.

\section{Dimensi Interpersonal dalam Interaksi dan Komunikasi}

Dalam sebuah proses interaksi dan komunikasi, ada dimensi internal individu (interpersonal) yang turut berkontribusi terhadap berkualitasnya proses tersebut. Dimensi tersebut meliputi: keterbukaan, empati, dukunga, rasa positif, dan kesetaraan. Secara lebih jelas, dimensi-dimensi tersebut diuraikan capaiannya dalam gambar 3 berikut:

Gambar 3. Sebaran Frekuensi Dimensi Internal dalam Interaksi dan Komunikasi Interpersonal Penasehat Akademik dengan Mahasiswa

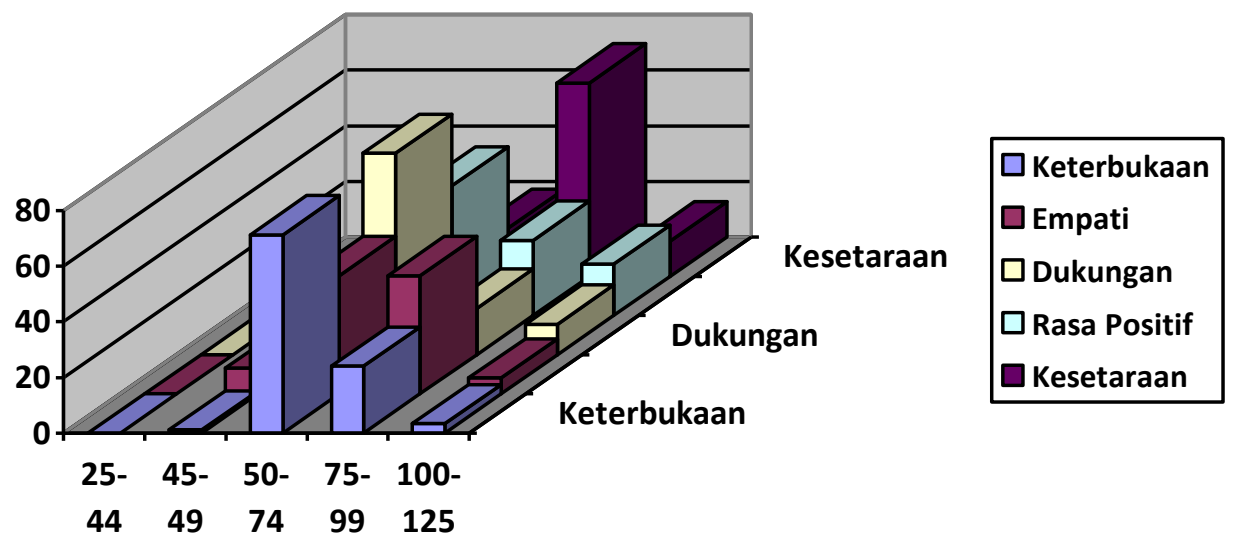

Sumber: Olahan Kuesioner (2018)

Berdasarkan gambar di atas dapat dijelaskan bahwa pendapat mahasiswa tentang keterbukaan penasehat akademik (PA) dalam mengkonsultasikan hasil mereka cukup bervariasi. Dari 250 responden, terdapat 148 orang atau 59,2\% yang 
berpendapat bahwa keterbukaan penasehat akademik rendah, 77 orang atau 30,8\% yang menyatakan sdang, 25 orang atau 1,0\% yang menyatakaan tinggi.

Berdasarkan gambaran di atas dapat dikemukakan terkait proses pembimbingan atau konsultasi mahasiswa ke penasehat akademiknya bahwa mereka memerlukan "keterbukaan" yang lebih tinggi dibandingkan sebelumnya terutama mahasiswa saat konsultasi. Aspek keterbukaan ini sangat penting karena dasar itulah dosen penasehat akademik memberikan masukan. Dalam konteks komunikasi interpersonal, hal tersebut mengindikasi tidak lancarnya pesan individu diterima oleh para pelaku komunikasi tersebut.

Selain aspek "keterbukaan" di atas, komunikasi interpersonal antara Penasehat Akademik dengan mahasiswa juga dapat dilihat dari "tingkat dukungan atau respon" penasehat akademik terhadap mahasiswa yang bermaksud berkonsultasi. Dari 250 responden, terdapat 135 orang atau 54\% yang berpendapat bahwa dukungan penasehat akademik rendah, 61 orang atau 24,4\% yang menyatakan sedang, 54 orang atau 21,6\% yang menyatakaan tinggi. Uraian ini memperlihatkan betapa rendahnya dukungan atau respon penasehat akademik terhadap komunikasi interpersonal mereka. Untuk mengatasi hal tersebut, maka hal yang harus dilakukan oleh penasehat akademik dengan mahasiswa adalah meningkatkan intensitas komunikasi mereka.

Terkait hal di atas, maka salah seorang Penasehat Akademik menyatakan kesiapannya membantu setiap kesulitan yang dialami mahasiswa dalam hubungannya dengan kegiatan akademik. Ia mengemukakan:

"Terkadang mahasiswa kurang melakukan komunikasi dengan para penasehat akademiknya. Salah satu faktor yang menyebabkan mahasiswa kurang mengkonsultasikan permasalahan akademiknya pada penesehat akademik adalah perasaan segan, malu-malu, tidak enak. Akan tetapi ada beberapa mahasiswa yang juga secara aktif berkonsultasi dengan penasehat akademik." (Wawancara, 18 September 2018)

Selanjutnya, bentuk dukungan penasehat akademik terhadap mahasiswa bukan saja dalam mengkonsultasikan permasalahan hasil belajar tetapi juga dalam perencanaan studi. 
Gambaran tentang aspek dukungan penasehat akademik (PA) dalam mengkonsultasikan rencana studi sangat beragam. Dari 250 responden mahasiswa, terdapat 174 orang atau 69,6\% yang berpendapat bahwa dukungan penasehat akademik rendah, 44 orang atau 17,6\% yang menyatakan sedang, dan 32 orang atau $12,8 \%$ yang menyatakaan tinggi. Kondisi tersebut memberikan gambaran bahwa dukungan penasehat akademik dalam perencanaan studi mahasiswa berada dalam kategori cukup. Berdasarkan kondisi tersebut seharusnya penasehat akademik lebih intensif memberikan kesempatan kepada mahasiswa untuk melakukan konsultasi, selain itu mahasiswa juga harus dituntut untuk lebih terbuka dan tidak segan untuk melakukan konsultasi.

Uraian tersebut diperkuat oleh pernyataan salah seorang penasehat akademik sebagai berikut:

"Setiap dosen yang menjadi penasehat akademik menyadari akan kewajibannya dalam memberikan dukungan moril kepada mahasiswa dalam menyelesaikan masa studinya. Meskipun kemudian, yang menjadi permasalahan adalah terkadang mahasiswa juga kurang memperhatikan prestasi belajarnya atau paling tidak kondisi permasalahan yang dihadapi dalam hubungannya dengan kegiatan akademiknya. Kondisi tersebut kemudian berdampak pada terjadinya kesalahan komunikasi di antara mereka karena penasehat akademik tidak mengetahui permasalahan mahasiswa sehingga nasehat yang diberikan terkadang kurang tepat." (Wawancara, 15 September 2018)

Mencermati uraian di atas, maka salah satu faktor yang menyebabkan kurangnya komunikasi personal antara penasehat akademik dengan mahasiswa adalah kondisi yang terjadi pada saat berlangsung komunikasi. Kondisi yang dimaksud adalah gaya komunikasi, misalnya penasehat akademik dengan gaya humor dan menyenangkan akan lebih memotivasi mahasiswa untuk melakukan komunikasi, berbeda dengan dosen dengan gaya komunikasi yang kaku justru dapat menyebabkan mahasiswa merasa takut mendekatinya.

Berikut ini adalah gambar yang menjelaskan tentang rasa positif dalam interaksi dan komunikasi pada saat penasehat akademik saat melakukan interaksi dan komunikasi dengan mahasiswa. 
Gambar 4. Sebaran Frekuensi Kondisi Interaksi dan Komunikasi Penasehat Akademik dengan Mahasiswa

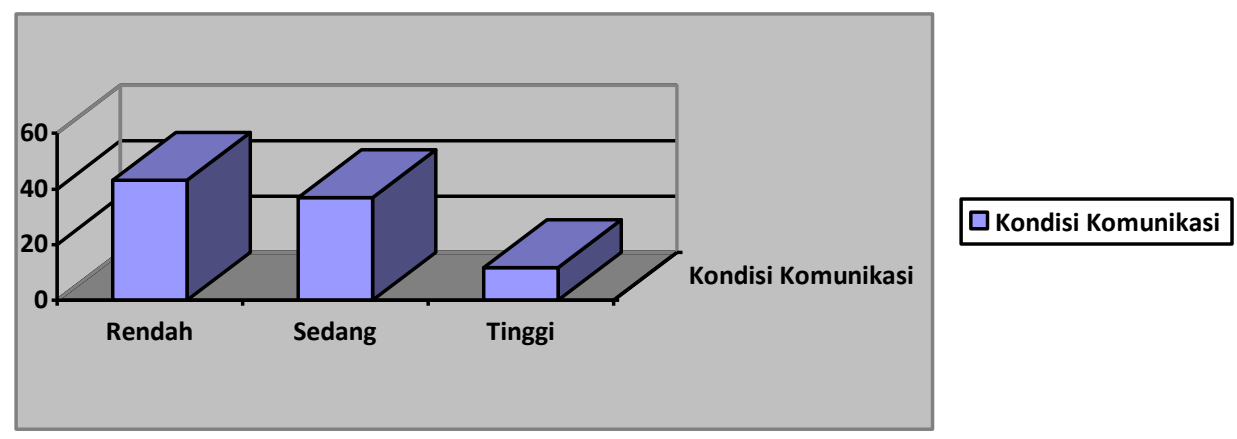

Sumber: Olahan Kuesioner (2018)

Berdasarkan gambar di atas, dapat dijelaskan bahwa dari 250 responden, terdapat 108 orang atau 43,2\% yang berpendapat bahwa suasana atau rasa positif dalam komunikasi penasehat akademik rendah, 92 orang atau 36,8\% yang menyatakaan sedang, dan 29 orang atau $11,6 \%$ yang menyatakan tinggi.

Berdasarkan gambar di atas dapat disimpulkan bahwa sebagian besar mahasiswa beranggapan dosen sebagai penasehat akademik berada pada tingkatan cukup rasa positifnya. Keadaan ini mengindikasikan bahwa dosen sebaiknya lebih membuka diri dan tidak menjaga jarak dengan mahasiswa sehingga mahasiswa lebih mudah mengungkapkan permasalahan akademiknya. Hal tersebut sebagaimana dinyatakan oleh salah seorang penasehat akademik yang pada dasarnya sudah cukup membuka ruang kepada mahasiswa yang ingin melakukan konsultasi, dan bahkan sudah mencantumkan kontak person supaya mahasiswa mudah menghubungi dosen sebagai penasehat akademiknya.

Uraian di atas memberikan penjelasan bahwa pihak dosen sebagai penasehat akademik juga sudah berusaha untuk membangun komunikasi personal dengan mahasiswa.

Berkaitan dengan tingkat empati penasehat akademik (PA) dalam mengkonsultasikan rencana studi bervariasi. Dari 250 responden, terdapat 115 orang atau $46 \%$ yang berpendapat bahwa tingkat empati penasehat akademik 
tinggi, terdapat 105 orang atau $42 \%$ yang berpendapat sedang, 20 orang atau $12 \%$ yang berpendapat rendah.

Gambar 5. Sebaran Frekuensi Tingkat Empati Penasehat Akademik dengan Mahasiswa

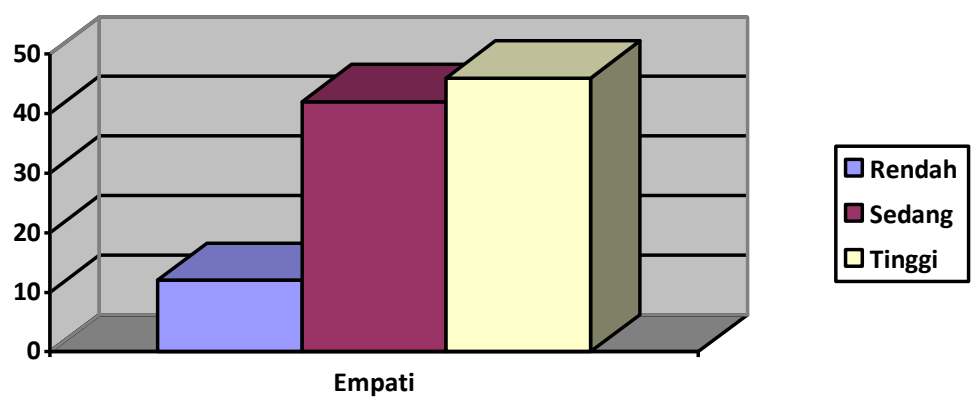

Sumber: Olahan Kuesioner (2018)

Selain rasa empati, keterbukaan, rasa positif, dan dukungan, tingkat kesetaraan antara penasehat akademik dengan mahasiswa juga menentukan intensitas dalam komunikasi personal.

Menyangkut tingkat kesetaraan penasehat akademik (PA) dalam mengkonsultasikan rencana studi juga sangat bervariasi. Dari 250 responden, terdapat 167 orang atau 66,8\% yang berpendapat bahwa suasana komunikasi penasehat akademik tinggi, 53 orang atau $21,2 \%$ yang menyatakan sedang, 30 orang atau $12 \%$ yang menyatakan rendah.

Gambar 5. Sebaran Frekuensi Tingkat Kesetaraan Penasehat Akademik dengan Mahasiswa

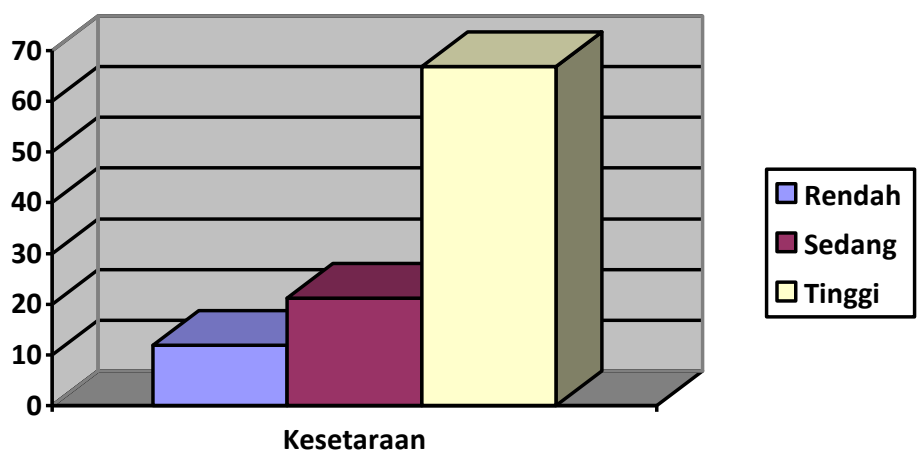

Sumber: Olahan Kuesioner (2018) 
Mencermati semua nilai dan kategori dari dimensi dalam interaksi dan komunikasi interpersonal di atas, dapat diuraikan bahwa pada dasarnya interaksi dan komunikasi yang berlangsung sudah sering terjadi dan bahkan bisa berlangsung lama. Tetapi, aspek interpersonal yang harus dipenuhi saat konsultasi tidaklah terjadi atau kalaupun terjadi maka hasilnya tidak maksimal sebagaimana seharusnya. Dari 5 dimensi, hanya 2 terkategori tinggi yaitu empati dan kesetaraan. Sisanya kategori rendah yaitu keterbukaan, dukungan, dan rasa positif. Mencermati gambaran ini, terkesan bahwa komunikasi lebih banyak terkait dengan curhat persoalan yang tidak terkait dengan akademik tetapi persoalan pribadi.

\section{PEMBAHASAN}

Data-data di atas menunjukkan bahwa sebagian besar pendapat mahasiswa tentang keterbukaan penasehat akademik (PA) dalam mengkonsultasikan hasil belajar masih dalam kategori cukup. Ini berarti sebagian besar mahasiswa menginginkan penasehat akademik lebih terbuka.

Dalam memahami kondisi di atas, telah terjadi ketidakefektifan dalam berkomunikasi antara penasehat dengan mahasiswa. Keefektifan berkomunikasi juga tergantung pada "siapa" serta "cara" penyampaian pesan kepada komunikan. Apabila kita berbicara kepada teman sejawat, orang tua, guru dan pimpinan, tentu harus menentukan sikap terlebih dahulu di mana kita berada, posisi apa yang kita perankan. Setelah kita dapat mendefinisikan diri kita pada suatu posisi tertentu, maka selanjutnya dapatlah kita sampaikan pesan dengan "cara" dan sikap yang tepat agar dapat mencapai sasaran yang kita inginkan.

Jika kondisi komunikasi interpersonal antara penasehat akademik dengan mahasiswa dihubungkan dengan teori Model peranan maka di sini dosen hanya memainkan peranannya sesuai dengan "naskah" (aturan) yang telah dibuat akademik. Hubungan interpersonal berkembang baik bila setiap individu bertindak sesuai dengan expedisi peranan (role of expectation) dan tuntutan 
peranan (role demands), memiliki keterampilan peranan (role skills), dan terhindari dari konflik peranan dan kerancuan peranan.

Dalam konteks penelitian ini, maka komunikasi antar pribadi dinilai paling ampuh dalam kegiatan mengubah sikap, kepercayaan, opini, dan perilaku komunikan. Alasannya adalah karena komunikasi berlangsung tatap muka. Komunikasi pribadi umumnya berlangsung tatap muka (face to face). Oleh karena anda dengan komunikan anda itu saling bertatap muka, maka terjadilah kontak pribadi (personal contact); pribadi anda menyentuh pribadi komunikan anda. Ketika anda menyampaikan pesan, umpan balik berlangsung seketika (immediate feedback), anda langsung mengetahui respon komunikan anda.

Oleh karena keampuhannya mengubah sikap, kepercayaan opini dan perilaku komunikan, maka bentuk komunikasi banyak digunakan untuk komunikasi persuasif yakni suatu teknik komunikasi secara psikologis manusiawi yang sangat halus, luwes berupa ajakan, bujukan atau rayuan. Oleh karena itu, penasehat akademik seharusnya memainkan peran sebagai peranan (role demands) sekaligus bertindak sebagai harapan peranan (role of expectation) dan memiliki keterampilan peranan (role skills). Peran yang diharapkan dimainkan oleh dosen adalah apa yang diharapkan oleh mahasiswa yaitu keterbukaan. Selain itu dosen juga dituntut memiliki keterampilan peranan termasuk keterampilan mengembangkan komunikasi yang efektif.

\section{PENUTUP}

Hubungan interpersonal dapat dipandang sebagai sistem dengan siftatsifatnya. Untuk menganalisanya kita harus melihat pada karakteristik individuindividu yang terlibat, sifat-sifat kelompok dan sifat-sifat lingkungan. Setiap hubungan interpersonal harus dilihat dari tujuan bersama, metode komunikasi, ekspektasi dan pelaksanaan peranan, serta permainan yang dilakukan. Secara singkat, model interaksional mencoba menggabungkan model pertukaran, peranan dan permainan. 


\section{DAFTAR PUSTAKA}

Achmad, A.S. (1990). Manusia dan Informasi. Ujung Pandang: Hasanuddin University Press, 1990

Cangara, Hafied. (1998). Pengantar Ilmu Komunikasi, Jakarta: PT. Raja Grafindo Persada.

. (2007). Komunikasi Politik Konsep, Teori dan Strategi, Jakarta: PT. Raja Grafindo Persada.

Effendy, Onong Uchjana. (2003). Ilmu Komunikasi Teori dan Praktek, Bandung: PT. Remaja Rosdakarya.

Johnson, D.W. (1981). Reaching out. Interpersonal Effectiveness and SelfActualization. Englewood Cliffs: Prentice-Hall.

Littejohn, Stephen W. (1995). Theories of Human Communication. Fifth Edition, Humboldt State University, Wadsworth Publishing Company.

Mulyana, Deddy. (2008). Ilmu Komunikasi Suatu Pengantar. Bandung: PT. Rosda Karya.

Purwanto, Djoko. (2006). Komunikasi Bisnis. Jakarta: Penerbit Erlangga.

Rahmat, Jalaluddin. (2004). Psikologi Komunikasi. Bandung: Remaja Rosdakarya.

Sendjaja, Sasa Djuarsa, dkk. (1993). Teori Komunikasi, Jakarta: Universitas Terbuka.

Soekanto, Soerjono. (1990). Pengantar Sosiologi. Jakarta: Rajagrafindo Persada.

Wiryanto. (2004). Pengantar Ilmu Komunikasi. Jakarta: PT. Grasindo. 